\title{
Örgütsel Sinizmin İşten Ayrılma Niyetine Etkisinde Yaşın Düzenleyici Rolünün Incelenmesi (Investigating the Moderating Role of Age Factor on the Effect of Organizational Cynism on Intention to Leave)
}

\author{
Mustafa CANBEK iD $_{a}$ Engin KANBUR ${ }^{D} D_{b}$ \\ a Artvin Çoruh Üniversitesi, Hopa Meslek Yüksekokulu, Artvin, Türkiye, mcanbek@artvin.edu.tr \\ b Kastamonu Üniversitesi, Sivil Havacılık Yüksekokulu, Kastamonu, Türkiye, ekanbur@kastamonu.edu.tr
}

\begin{tabular}{|c|c|}
\hline MAKALE BİLGİsí & ÖZET \\
\hline Anahtar Kelimeler: & Amaç - Araştırmanın amacı, çalışanların örgütsel sinizm algılarının işten ayrılma niyeti üzerindeki \\
\hline $\begin{array}{l}\text { Örgütsel Sinizm } \\
\text { İşten Ayrılma Niyeti } \\
\text { Polis }\end{array}$ & $\begin{array}{l}\text { etkisinde yaş faktörünün moderatör rolünün incelenmesidir. } \\
\text { Yöntem - Araştırmanın verileri, Türk Polis Teşkilatı'nda görevli } 518 \text { polisten online olarak } \\
\text { hazırlanan anket formu aracllı̆̆yla toplanmıştır. }\end{array}$ \\
\hline Gönderme Tarihi 27 Şubat 2019 & $\begin{array}{l}\text { Bulgular - Araştırmanın doğrusal ve çoklu regresyon bulgularına göre; örgütsel sinizm ile alt } \\
\text { boyutlarından duyuşsal ve davranışsal boyutlarının işten ayrılma niyeti üzerinde pozitif ve anlamlı }\end{array}$ \\
\hline Revizyon Tarihi 1 Temmuz 2019 & bir etkisinin olduğu, ancak bilişsel alt boyutunun herhangi bir etkiye sahip olmadığı görülmüştür. \\
\hline Kabul Tarihi 25 Temmuz 2019 & $\begin{array}{l}\text { Düzenleyici role ilişkin process makro ile gerçekleştirilen moderatör analizi bulgularına göre; } \\
\text { araştırmada düzenleyici değişken olarak belirlenen yaş faktörünün örgütsel sinizm ve alt } \\
\text { boyutlarının işten ayrılma niyeti üzerindeki etkisinde herhangi bir düzenleyiciliğinin bulunmadığ1 } \\
\text { sonucuna ulaşılmıştır. }\end{array}$ \\
\hline Araştırma Makalesi & $\begin{array}{l}\text { Tartışma - Araştırmanın sorunsalı kapsamında, yaş değişkenin polislik mesleğinin beraberinde } \\
\text { getirdiği sorunlara yaklaşımda belirgin bir düzenleyici etkisinin olacağı tahmin edilmiştir. Ancak } \\
\text { araştırmada elde edilen sonuçlar öngörülenden farklı çıarak yaş değişkeninin polislerin örgütsel } \\
\text { sinizme bağlı olarak işten ayrılmalarına yönelmelerinde herhangi bir düzenleyici etkisinin } \\
\text { olmadığını ortaya koymaktadır. Bu çalışma ile polislerin işten ayrılma konusundaki eğilimleri } \\
\text { hakkında sonraki çalışmaların faydalanabileceği sonuçlar elde edilmiştir. }\end{array}$ \\
\hline
\end{tabular}

\begin{tabular}{|c|c|}
\hline ARTICLE INFO & ABSTRACT \\
\hline Keywords: & $\begin{array}{l}\text { Purpose - The aim of the research, it's investigate the moderating role of age on the effect of } \\
\text { organizational cynism on intention to leave. }\end{array}$ \\
\hline Intention to Leave & $\begin{array}{l}\text { Design/methodology/approach - Data of the research collected via online questionnaires from } 518 \\
\text { police officers who are working in Turkish Police Organization. }\end{array}$ \\
\hline $\begin{array}{l}\text { Received } 27 \text { February } 2019 \\
\text { Revised } 1 \text { July } 2019 \\
\text { Accepted } 25 \text { July } 2019\end{array}$ & $\begin{array}{l}\text { Findings - According to findings of liner regression and multiple regression analyses, } \\
\text { organizational cynism and it's subdimensions affective and behavioral cynism are significantly } \\
\text { effective on intention to leave but cognitive cynism has no effect on intention to leave. Results of the } \\
\text { moderator analysis implemented by the process macro showed age has no moderating effect on the } \\
\text { effects of cynism and relevant subdimensions on the intention to leave. }\end{array}$ \\
\hline $\begin{array}{l}\text { Article Classification: } \\
\text { Research Article }\end{array}$ & $\begin{array}{l}\text { Discussion - In the context of the research question, it's estimated that the age variable would have } \\
\text { a considerable moderating role in regards of the characteristic problems of policing profession. } \\
\text { However, findings were different than expected and showed that there is no moderating effect of } \\
\text { age on the effect of organizational cynism to intention to leave. Findings acquired with the research } \\
\text { are available for the next researchs which question to police officers' intention to leave trends. }\end{array}$ \\
\hline
\end{tabular}

\section{Giriş}

Çağdaş örgütler, çalışanlarının iş ve aile yaşamında olumsuz yansımaları görülebilen çeşitli durum ve gelişmelerden çalışanların korunabilmeleri için alınabilecek tedbirlere büyük önem vermektedirler. Ancak yine de çeşitli yapısal ve durumsal değişkenler, çalışanların; örgüte, yöneticilere veya çalışma arkadaşlarına şüphe ile yaklaşmalarına neden olabilmektedir. Hatta bunlara duyulan güvenin tamamen yitirilip gitmesi söz konusu olabilmektedir. Bağlı bulunulan örgüte, yöneticilere veya diğer çalışanlara karşı sözü edilen 
olumsuz tutum içerisinde olmak örgütsel sinizm olarak açılanabilir. Esasında günümüz örgütleri açısından istenmeyen, kaçınılan bir durum olmasına rağmen örgütsel sinizm hemen her alanda sıklıkla karşılaşılan bir durumdur. Araştırmacılar sinizmin oldukça yaygın bir biçimde iş dünyasında kendisini hissettirdiğine dikkati çekmektedirler (Dean, Brandes \& Dharwadkar, 1998: 341).

Bilim insanları ve iş dünyasında yer alan yöneticiler örgütlerde sinik davranışların bulunduğunu bilmelerine karşın bu kavramın bilimsel açıdan incelenmesi uzun yıllar boyunca mümkün olamamıştır (James, 2005: 2). Günümüzde ise örgütsel sinizm, pek çok araştırmacı tarafından incelenmekte ve çeşitli özellikleri nedeniyle örgütsel çıktılarının nasıl olabileceği tahmin edilmeye çalışılmaktadır (Davis \& Gardner, 2004; Byrne \& Hochwarter, 2008; Wilkerson, Evans \& Davis, 2008; Y1ldız, 2013; Kerse \& Karabey, 2017; Erarslan, Kaya \& Altındağ, 2018; Seymen \& Kırboğa, 2018; Mert \& Yılmaz, 2019). Bu örgütsel çıktıların biri de işten ayrılma niyetidir. İşten ayrılma niyeti, çalışanların örgütsel koşullardan memnun olmamaları neticesinde örgütten (işten) ayrılma yönünde ortaya koydukları negatif örgütsel davranışlar olarak belirtilebilir (Kanbur, 2018: 150). Bu bakımdan örgütsel sinizmin yapısının, özelliklerinin ve nedenlerinin iyi anlaşılması çalışanların işten ayrılmalarının ve buna bağlı olarak örgütün bilgi ve deneyim kaybının önüne geçilebilmesi açısından önem kazanmaktadır. Çünkü bilginin çok stratejik ve önemli olduğu günümüz örgütlerinde insan faktörünün önemi her geçen gün daha da artmaktadır (Genç, 2013: 59).

Yetenekli ve bilgili çalışanların örgüte kazandırılması ve örgüt bünyesinde kalmalarının sağlanması birçok bakımdan önemlidir. Aksi takdirde çalışanların işten ayrılmasına, örgüte kazandırılmış yeteneklerin ve bilgi birikiminin dolayısıyla kurumsal hafızanın yitirilmesine neden olabilmektedir. Bu bağlamda çalışanların sergiledikleri sinik davranışların işten ayrılma niyetleri üzerindeki etkisinin incelenmesinde yaş faktörünün herhangi bir düzenleyici etkisi olup olmadığının ortaya konulmasına ihtiyaç duyulmaktadır. Bu ihtiyaç aynı zamanda çalışmanın sorunsalını oluşturmaktadır. Bu sorunsal kapsamında değişkenlerle ilgili yazın incelemesi yapılmış olup, örgütsel sinizmin işten ayrılma niyeti üzerindeki etkisini ele alan sınırlı sayıda çalışma olmasına rağmen yaş faktörünün düzenleyici rolünü ele alan herhangi bir çalışmaya rastlanmamıştır $\mathrm{Bu}$ durum daha önce yazında ele alınmamış ve incelenmemiş bir konuyu araştırmak alan yazına katkı sağlama bakımından önem arz etmektedir. Bu bağlamda araştırmanın bundan sonraki kısmında sırasıyla ilgili kavramlar hakkında yazın taraması yapılacak. Ardından araştırmanın yöntemi ortaya konulacak ve araştırma bulgularına yer verilecek. Son olarak ise araştırma sonuçları değerlendirilerek gerekli önerilerde bulunulacaktır.

\section{Kavramsal Çerçeve}

\section{1. Örgütsel Sinizm}

Sinizm, bireyin çevresindeki diğer bireylere ve örgütlere güvenmemesi, onlar hakkında olumsuz düşünceye sahip olması durumudur. Bu durum beraberinde sinik kişiliği veya sinik davranışı ortaya çıkarmaktadır. Sinik kişi, insanların sergiledikleri davranışların bütünüyle kendi çıkarı için olduğuna inanan ve bu inancını çevresindekilere aşağılayıcı ve küçümseyici sözlerle ifade eden ve/veya bu yönde davranış sergileyen kişidir (Çakıcı \& Doğan, 2014: 80). Çalışanların çeşitli nedenlerle olumsuz bir tutum içerisinde olarak örgüte, yöneticilere ve diğer çalışma arkadaşlarına güven duymamaları ve şüpheyle yaklaşmaları sinik davranışlara örnek olarak gösterebilir (Erdost, Karacaoğlu \& Reyhanoğlu, 2007: 514). Örgütsel sinizm, çalışanların bağlı bulundukları örgütte kişisel çıkarların ön planda yer aldığına, adalet, dürüstlük ve samimiyetin bulunmadığına inanmaları şeklinde açıklanabilir (Üçok \& Torun, 2014: 233). Başka bir tanımda örgütsel sinizm, çalışanların örgütte yürütülen faaliyetlerin hakkaniyetine, doğruluğuna, etik ve ahlaki olmadığına ve kendi çıkarları doğrultusunda davranıldığına olan inancı olarak açıklanmaktadır (Bernerth, Armenakis, Field \& Walker, 2007: 311). Diğer bir tanıma göre örgütsel sinizm, çalışanın örgütüne karşı geliştirdiği negatif tutumlar ile ilgidir ve bu tutumlar çalışanı örgüte karşı negatif hisler beslemeye, eleştirel bir yaklaşım içine girmeye ve bu doğrultuda davranışlar sergilemeye yöneltmektedir (Abraham, 2000: 269; Davis \& Gardner, 2004: 442).

Örgütsel sinizm yazında; bilişsel, duyuşsal ve davranışsal örgütsel sinizm olmak üzere üç boyutta incelenmektedir (Dean, Brandes \& Dharwadkar, 1998: 345). Bu boyutların ilki, örgütün dürüstlükten, hakkaniyetten ve doğruluktan yoksun olduğuna dair inancı temsil eden bilişsel (inanç) boyutudur. Çalışanların zihninde örgütün adil olmadığı ve samimiyetten uzak olduğuna dair düşünceleri bu boyut kapsaminda değerlendirilmektedir. Sinik bireyler örgütün dürüstlük, adalet ve samimiyet gibi temel ilkelere ihanet ettiğine inanmaktadırlar (Kanbur \& Kanbur, 2015: 197). Örgütsel sinizmin ikinci boyutu, sinik 
bireylerin örgütle ilgili sadece düşünce ve inanç olarak değil duygusal olarak da olumsuz bir yaklaşım içinde olabileceklerini vurgulayan duyuşsal boyutudur (Naus, Iterson \& Roe, 2007: 196). Örgütsel sinizm sakin veya hissiz bir değerlendirme olarak görülmemektedir. Aksine çok güçlü olumsuz duyguları barındırabileceği savunulmaktadır. Bireyin örgütüne karşı duyduğu kin, öfke ve nefret gibi duygular hissetmesi bu kapsamda ele alınmaktadır (Balay, 2013: 127; Kanbur \& Canbek, 2018: 40). Örgütsel sinizmin son boyutu ise ilk iki boyutun etkisi ile meydana gelebilecek olan davranış boyutudur. Örgütü açık bir biçimde veya ima yoluyla küçümseme veya aşağılama, gelecekte örgütün eylemleri neticesinde elde edilecek sonuçlarla ilgili karamsar tahminlerde bulunma gibi çeşitli biçimlerde meydana gelebilecek olan olumsuz davranışlar bu boyutta değerlendirilmektedir (Dean, Brandes \& Dharwadkar, 1998: 345-346). Bireylerin, tanımlarda ifade edildiği örgütlerine karşı olumsuz bir yaklaşım içinde bulunmaları örgütlerine karşı duydukları güven ve işten duydukları tatmin duygusunun ayrıca örgüte olan bağlılıklarının azalmasına, işe ve örgüte karşı yabancılaşmalarına neden olabileceği ifade edilmektedir (Üçok \& Torun, 2014: 233-234; Korkmaz, 2011: 40-48). Dolayısıyla örgütsel sinizmin hem birey hem de örgüt açısından çeşitli olumsuz sonuçların ortaya çımasına yol açabileceği değerlendirilebilir.

\section{2. İşten Ayrılma Niyeti}

İşten ayrılma niyeti, çalışanların, mevcut işyerinden ayrılmaya yönelik geliştirdikleri bilinçli bir düşünce olarak tanımlanabilir (Tett \& Meyer, 1993: 262). Bu tanımda olduğu gibi diğer pek çok araştırmacı da işten ayrılma niyetini tanımlarken vurguladıkları husus, çalışanların bilinçli ve kararlı bir şekilde işten ayrılmaya niyetlendiklerini göstermektedir (Appolis, 2010: 23; Emberland \& Rundmo, 2010: 453). Çalışanların işten ayrılmaya karar vermelerinde etkili olabileceği ifade edilen çok sayıda örgütsel ve bireysel faktörden söz etmek mümkündür. Çalışanların, örgüt kültürü ve değerleri, çalışma arkadaşları ile ilişkiler, kariyer geliştirme fırsatları, örgüt bünyesindeki rol, talep ve beklentiler, adalet, ödüllendirme sistemi ile ücretlendirme gibi konularda edinecekleri inanç, algı, duygu ve düşünceler onların işten ayrılmaya karar vermelerinde etkili olabilmektedir (Yalçın, 2017: 1). Bu kapsamda işten ayrılma niyetinin neden ve sonuçlarını keşfetme amacı taşıyan çok sayıda araştırmanın yazına kazandırıldığı hatta işten ayrılma sürecine dair çeşitli özelliklerin incelenmesini sağlayan modellerin geliştirildiği gözlemlenmektedir (Canbek, 2017: 4).

İşten ayrılma niyeti örgütler açısından kritik öneme sahip olması nedeniyle birçok araştırmacı bu kavram üzerinde çeşitli araştırmalar gerçekleştirmişlerdir (Bibby, 2008; Yürür \& Ünlü, 2011; Erkuş ve Fındıklı, 2013; Onay ve Kılc1, 2013; Bolat, Bolat, Seymen, \& Katı, 2017; Tanrıverdi, Koçaslan, \& Taştan, 2018). Suresh ve Krishnaraj (2015) kendisine belirli bir yatırım yapılan çalışanın işten ayrılmasıyla bilgi, sermaye, yetenek, zaman ve tecrübe kaybı yaşanacağına dolayısıyla çok yönlü bir kaybın söz konusu olduğuna dikkati çekmektedirler. İşten ayrılma niyeti, çalışanların örgütün kendilerine sunmuş olduğu şartlardan (iş yükü, çalışma saatleri, kariyer planlama, terfi, ücret vb.) memnun olmamaları halinde örgütten ayrılma konusunda istekli olmaları durumudur ve çalışanların örgütten ayrılma niyetleri örgüte birçok konuda (maliyet artışı, tecrübe kaybı gibi) olumsuzluk yaratmaktadır (Beğenirbaş \& Çalışkan, 2014: 114; Çelik \& Çıra, 2013: 11; Demir \& Tütüncü, 2010: 67; Kanbur, 2018: 150). Bu bağlamda çalışanların işten ayrılma niyetleri üzerinde etkili olduğu düşünülen faktörlerden biri de örgütsel sinizmdir. Örgütsel sinizmin, işten ayrilma niyeti üzerindeki etkisini inceleyen çeşitli çalışmalarda elde edilen sonuçlar örgütsel sinizmin çalışanların işten ayrılma yönünde verecekleri kararlarda etkili olabileceğini göstermektedir (Polat \& Meydan, 2010; Yasım \& Uğur, 2016: 568; Torun, 2016; Beheiri, Ahmed \& Aboul Ela, 2018: 24).

\subsection{Kuramsal Altyapı ve Hipotez Geliştirme}

Örgütsel sinizm yani çalışanların sinik davranışlar sergilemesi ve işten ayrılma niyeti, örgütü olumsuz etkileyen iki olumsuz iş davranışı olarak karşımıza çıkmaktadır. Çalışanların sinik davranışlar göstermesinin temelinde, aşırı iş yükü, işe bağlı gerginlik, ücret, terfi, kariyer beklentilerinin tam ve adil olarak karşılanmaması, iletişimde yaşanan eksiklikler, fiziksel ortamın uygun olmaması, çalışma saatleri ve kararlara katılamama gibi unsurlar yer almaktadır. Bu unsurların bir sonucu olarak ise çalışanlarda verimlilik düşüşü ve buna bağlı olarak performans eksikliği, örgüte bağlılıkta azalma, işe devamsızlık ve işten ayrılma niyetinin oluşması doğal bir sonuç olarak görülmektedir (Erbil, 2013: 50). Polat ve Meydan (2010) 176 özel sektör çalışanı ile gerçekleştirdikleri çalışmalarında, örgütsel sinizm ile işten ayrılma niyeti arasında pozitif ve anlamlı bir ilişkinin olduğunu, çalışanların sergiledikleri sinik davranışların zamanla onların işten ayrılma niyetlerini artırdığını saptamışlardır. Güzel ve Ayazlar (2014) dört ve beş yıldızlı otel 
işletmelerinde çalışanlarla yürüttükleri araştırmalarında, örgütsel sinizm ile işten ayrılma niyeti arasında pozitif bir ilişkinin olduğunu, çalışanların örgüte karşı duydukları olumsuz tutumların bir sonucu olarak işten ayrılma niyetlerinin oluştuğu sonucuna varmışlardır. Torun (2016) doktora çalışmasında ise aynı şekilde örgütsel sinizm ile işten ayrılma niyeti arasında pozitif bir ilişkinin olduğunu belirtmektedir. Bu bağlamda teorik altyapı ve yapılan görgül çalışmalara dayanılarak algılanan örgütsel sinizm ve işten ayrılma niyeti arasındaki ilişkiye yönelik aşağıdaki hipotezler geliştirilmiştir.

$\mathrm{H}_{1}$. Örgütsel sinizmin, işten ayrılma niyeti üzerinde pozitif etkisi vardır.

$\mathrm{H}_{2}$. Bilişsel sinizmin, işten ayrılma niyeti üzerinde pozitif etkisi vardır.

$\mathrm{H}_{3}$. Duyuşsal sinizmin, işten ayrılma niyeti üzerinde pozitif etkisi vardır.

$\mathrm{H}_{4}$. Davranışsal sinizmin, işten ayrılma niyeti üzerinde pozitif etkisi vardır.

Örgütsel sinizm ile işten ayrılma niyeti arasındaki, yazında belirtilen pozitif ilişkide yaşın düzenleyici rolünün incelendiği bir çalışmaya rastlanmamıştır. Bu bağlamda yaşın düzenleyici rolünün incelenmesi ve bulgularının paylaşılması amacıyla aşağıdaki hipotezler geliştirilmiştir.

H5. Örgütsel sinizmin, işten ayrılma niyeti üzerindeki etkisinde yaşın düzenleyici etkisi vardır.

$\mathrm{H}_{6}$. Bilişsel sinizmin, işten ayrılma niyeti üzerindeki etkisinde yaşın düzenleyici etkisi vardır.

H7. Duyuşsal sinizmin, işten ayrılma niyeti üzerindeki etkisinde yaşın düzenleyici etkisi vardır.

H8. Davranışsal sinizmin, işten ayrılma niyeti üzerindeki etkisinde yaşın düzenleyici etkisi vardır.

Araştırmada örgütsel sinizmin ve alt boyutlarının işten ayrılma niyeti üzerindeki etkisinde yaş değişkenin düzenleyici etkisini gözlemlemek amacıyla teorik altyapı ve yapılan görgül çalışmalara dayanılarak geliştirilen hipotezler ışı̆̆ında oluşturulan araştırma modeli aşağıda sunulmaktadır.

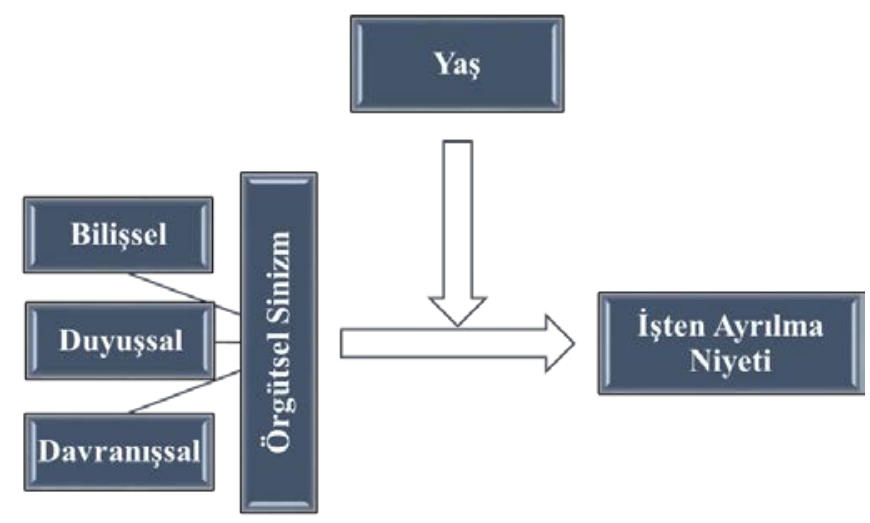

Şekil 1 - Araştırma Modeli

\section{Yöntem}

\subsection{Amaç ve Önem}

Araştırmada polislerin örgütsel sinizm düzeylerinin işten ayrılma niyetleri üzerindeki etkisinde yaş değişkeninin düzenleyici bir etkiye sahip olup olmadığı incelenmeye çalışılmıştır. Polislik mesleğine özgü olarak yaş değişkenin örgütsel konularla baş etmede düzenleyici bir etkisinin olabileceği değerlendirilmektedir. Polislerin mesleğin erken dönemlerinde karşılaştıkları olaylar ve durumlar hakkındaki değerlendirmeleri ile ileri yaşlarda yapacak oldukları değerlendirmelerin farklı olabileceği düşünülebilir. Ayrıca belirli bir yaştan sonra başka bir işte başarılı olma ihtimalinin azalabileceği düşüncesiyle polislerin örgütsel konulara olan yaklaşımlarında daha 1lımlı bir tutum içerisinde olabilecekleri akla gelmektedir. Dolayısıyla yaş değişkenin mesleğin beraberinde getirdiği sorunlara yaklaşımda belirgin bir düzenleyici etkisinin olacağı ileri sürülebilir.

Öte taraftan polisler arasında örgütsel sebeplere bağlı olarak emniyet teşkilatından ayrılma ve başka bir meslek seçimi konusunda kayda değer bir eğilim söz konusudur. Üstelik polislerin alternatif iş imkânları konusunda yaşa bağlı olarak farklı yaklaşımlara sahip oldukları ifade edilmektedir (Canbek, 2017: 62-109). $\mathrm{Bu}$ açıklamalar ışı̆̆ında polislerin örgütsel sinizm düzeylerinin işten ayrılma niyeti üzerindeki etkisinde yaş değişkeninin düzenleyici etkisinin incelenmesi; hem polislerin işten ayrılma niyetleri konusundaki 
yaklaşımlarının daha iyi anlaşılabilmesi hem de yaş değişkeninin örgütsel sinizm ve işten ayrılma niyeti ile başa çıkmada nasıl bir fonksiyonunun olabileceğini keşfetme bakımından önem taşımaktadır.

\subsection{Evren, Örneklem ve Kisıtlar}

Araştırma evrenini emniyet teşkilatında farklı birim ve hiyerarşik kademede görev yapmakta olan yaklaşık 300 bin polis oluşturmaktadır. Kolayda örnekleme yöntemiyle ulaşılan polislerden anket yoluyla veriler elde edilmeye çalışılmıştır. Bu bağlamda araştırmada mümkün olan en çok katılımın sağlanabilmesi için anket çalışması online olarak gerçekleştirilmiştir. Araştırma evreninin büyüklügüne bağlı olarak $\alpha=.05$ güven düzeyi ve \pm .05 hata seviyesinde en az 384 çalışandan oluşan bir örneklem grubu, evreni temsil edilebilecek niteliktedir (Altunışık vd., 2004: 125; Gürbüz \& Şahin, 2016: 132). Hazırlanan online anket formu polislerin üye oldukları sosyal medya gruplarında tanıtılmış ve sonuç olarak yaklaşık 530 anket formunun doldurulması sağlanmıştır. Çeşitli eksiklikler nedeniyle çıkarılan formların ardından 518 anket formu analizlere dâhil edilmiştir. Her araştırmanın sahip olduğu gibi bu araştırmanın da bazı kısıtları bulunmaktadır. Öncelikle araştırmanın sadece polisler ile yürütülmesi, araştırma verilerinin toplaması için online anket yönteminin kullanılması ve kullanılan ölçekler araştırmanın kısıtları arasında yer almaktadır.

\subsection{Veri Toplama Yöntemi ve Ölçekler}

Araştırmada veri toplama yöntemi olarak online anket formu kullanılmıştır. Araştırmada polislerin örgütsel sinizm düzeylerini tespit edebilmek amacıyla Dean, Brandes ve Dharwadkar (1998) tarafından geliştirilen ve Türkçe'ye uyarlaması, geçerlilik ve güvenilirlik $(\alpha=0.93)$ çalışmaları Kalağan (2009) tarafından yapılan "Örgütsel Sinizm Ölçeği" kullanılmıştır. Ölçek, 13 maddeden ve 3 boyuttan (bilişsel, duyuşsal, davranışsal) oluşmaktadır. Karacaoğlu ve İnce (2012) çalışmalarında ölçeğin güvenilirliğini $\alpha$ değeri ile 0.91, örgütsel sinizmin alt boyutlarından duyuşsal boyut için 0.94 , bilişsel boyut için 0.87 ve davranışsal boyut için ise 0.82 olarak tespit etmişlerdir. Ölçeğin puanlaması, 5'li Likert ölçeğine uygun olarak hazırlanmıştır.

Polislerin işten ayrılma niyetini belirlemek amacıyla Cammann, Fichman, Jenkins \& Klesh (1983) tarafından geliştirilen ve daha sonra Mimaroğlu (2008) tarafından Türkçe'ye uyarlaması yapılan "İşten Ayrılma Niyeti Ölçeği" kullanılmıştır. Ölçek tek boyut ve 3 maddeden oluşmaktadır. Ölçeğin puanlaması, 5 'li Likert ölçeğine uygun olarak hazırlanmıştır.

\subsection{Güvenilirlik ve Faktör Analizleri}

Araştırmada kullanılan örgütsel sinizm ölçeği ve işten ayrılma niyeti ölçeğine ait iç tutarlılık analizi Cronbach Alfa $(\alpha)$ iç tutarlılık değeri ile incelenmiştir. Yapılan analizlerde örgütsel sinizm ölçeğine ait $\alpha$ değeri 0.88 ve işten ayrılma niyeti ölçeğine ait $\alpha$ değeri 0.91 şeklinde bulunmuştur. Her iki ölçeğe ait $\alpha$ değerlerinin güvenilirlik için kabul edilen sınır olan 0.70'ten büyük oldukları görülmektedir (Gürbüz \& Şahin, 2016: 132). Ölçeklerin yapı geçerliliklerin test edilebilmesi amacıyla faktör analizi uygulanmıştır. Faktör analizi ve güvenilirlik analizi ile elde edilen bulgular Tablo 1'de gösterilmiştir.

Tablo 1. Faktör ve Güvenilirlik Analizi Sonuçları

\begin{tabular}{llcccc}
\hline \hline \multicolumn{2}{c}{ Faktörler } & $\begin{array}{c}\text { Madde } \\
\text { Sayısı }\end{array}$ & $\begin{array}{c}\text { Faktör } \\
\text { Yük } \\
\text { Aralığı }\end{array}$ & $\begin{array}{c}\text { Açıklanan } \\
\text { Varyans (\%) }\end{array}$ & $\begin{array}{c}\text { Cronbach } \\
\text { Alpha }(\boldsymbol{\alpha})\end{array}$ \\
\hline \hline Örgütsel Sinizm & 13 & $.507-.947$ & 60.155 & .881 \\
& $>$ Bilişsel Boyut & 5 & $.507-.731$ & 36.420 & .763 \\
& $>$ Duyuşsal Boyut & 4 & $.756-.947$ & 12.620 & .953 \\
& $>$ Davranış Boyutu & 3 & $.692-.830$ & 11.115 & .855 \\
İANÖ & İşten Ayrılma Niyeti & 3 & $.914-.951$ & 86.21 & .910 \\
\hline \hline
\end{tabular}

\begin{tabular}{ll}
\hline \hline ÖSÖ İANÖ & : Örgütsel Sinizm Ölçeği \\
: İşten Ayrılma Niyeti Ölçeği
\end{tabular}

Tablo 1'de yer alan bulgular incelendiğinde; örgütsel sinizm ölçeği faktör yükleri .507 ile 947 arasında değişen ve toplam varyansı \%60.155 olarak açıklayan üç faktör grubundan oluşmakta ve güvenilirliği 
\%88.1'dir. Ayrıca işten ayrılma ölçeği faktör yükleri .914 ile .951 arasında değişen ve toplam varyansı \%86.21 olarak açılayan tek faktör grubundan oluşmakta ve güvenilirliği \%91.0'dir. Faktör analizinden elde edilen sonuçlarda, örgütsel sinizm ölçeğinin özgün formunda davranış boyutunu ölçmek için kullanılan ifadeler arasında yer alan "Çalıştığım kurumdan ve çalışanlarından bahsedildiğinde, birlikte çalıştı̆̆ım kişilerle anlamlı bir şekilde bakışırız" ifadesi çapraz yükleme özelliği göstererek hem duyuşsal boyut (.382) hem de bilişsel boyut (.363) gruplarında birbirine çok yakın değerler aldığı görülmüştür. Dolayısıyla sözü edilen ifade ile ilgili çapraz yükleme sorunu ile karşılaşılmıştır. Bu sorunun giderilmesi için iki farklı faktör grubunda birbirine çok yakın derecede faktör yük değerine sahip ifadenin analizlerden çıarılması gerekmektedir (Gürbüz \& Şahin, 2014: 304). Bu doğrultuda söz konusu ifade çıkarılarak analizlere devam edilmiştir.

\section{Bulgular}

\subsection{Korelasyon Analizine İlişkin Bulgular}

Araştırma değişkenleri olan örgütsel sinizm, işten ayrılma niyeti ve yaş değişkenlerinin aralarındaki korelasyonun gözlemlenmesi amacıyla korelasyon analizi gerçekleştirilmiştir. Araştırmada örgütsel sinizmin alt boyutları olan bilişsel (inanç), duyuşsal ve davranışsal boyutları da incelenme kapsamında ele alındığı için korelasyon analizine dahil edilmiştir. Korelasyon analizine ilişkin bulgular Tablo 2' de gösterilmiştir.

Tablo 2. Değişkenler Arasındaki Korelasyon Analizi

\begin{tabular}{lcccccc}
\hline \hline Ölçekler & $\begin{array}{c}\text { Örgütsel } \\
\text { Sinizm }\end{array}$ & $\begin{array}{c}\text { Bilişsel } \\
\text { Boyut }\end{array}$ & $\begin{array}{c}\text { Duyuşsal } \\
\text { Boyut }\end{array}$ & $\begin{array}{c}\text { Davranış } \\
\text { Boyutu }\end{array}$ & $\begin{array}{c}\text { İşten } \\
\text { Ayrılma } \\
\text { Niyeti }\end{array}$ & Yaş \\
\hline \hline Örgütsel Sinizm & 1 & & & & & \\
• Bilişsel Boyut & $.742^{* *}$ & 1 & & & & \\
• Duyuşsal Boyut & $.834^{* *}$ & $.407^{* *}$ & 1 & & & \\
• Davraniş Boyutu & $.734^{* *}$ & $.317^{* *}$ & $.453^{* *}$ & 1 & & \\
İşten Ayrılma Niyeti & $.520^{* *}$ & $.220^{* *}$ & $.578^{* *}$ & $.380^{* *}$ & 1 & 1 \\
Yaş & $-.099^{*}$ & -.022 & -.079 & $-.155^{* *}$ & $-.115^{* *}$ & 1 \\
\hline \hline
\end{tabular}

${ }^{* *} \mathrm{p}<0.01$ düzeyinde anlamlıdır.

* $\mathrm{p}<0.05$ düzeyinde anlamlıdır.

Tablo 2'de yer alan örgütsel sinizm ve alt boyutları ile işten ayrılma niyeti ve yaş değişkenleri arasındaki korelasyon analizine ilişkin bulgular incelendiğinde; işten ayrılma niyetinin, örgütsel sinizm $(r=.520 ; p<.01)$, örgütsel sinizmin alt boyutları olan bilişsel (inanç) boyut $(\mathrm{r}=.220 ; \mathrm{p}<.01)$, duyuşsal boyut $(\mathrm{r}=.578 ; \mathrm{p}<.01)$ ve davranışsal boyut ile $(\mathrm{r}=.380 ; \mathrm{p}<.01)$ aralarında pozitif yönlü ve anlamlı korelasyon olduğu görülmektedir.

\subsection{Regresyon Analizine İlişkin Bulgular}

Örgütsel sinizm ve alt boyutlarının işten ayrılma niyeti üzerindeki etkisini gözlemlemek dolayısıyla araştırma hipotezlerini test etmek amacıyla regresyon analizi gerçekleştirilmiştir. Regresyon analizine ilişkin bulgular Tablo 3'te sunulmaktadir.

Tablo 3. Regresyon Analizine İlişkin Bulgular

Bağımlı Değişken: İşten Ayrılma Niyeti

\begin{tabular}{lccccc}
\hline Bağımsız değişkenler & $\mathbf{R}^{2}$ & $\mathbf{F}$ & $\boldsymbol{\beta}$ & $\mathbf{t}$ & $\mathbf{p}$ \\
\hline \hline Örgütsel Sinizm & .353 & 93.503 & 1.72 & 7.836 & $.000^{* *}$ \\
• Bilişsel Boyut & & & -.062 & 1.080 & .280 \\
• Duyuşsal Boyut & & & .523 & 12.532 & $.000^{* *}$ \\
• Davranış Boyutu & & & .151 & 3.849 & $.000^{* *}$ \\
\hline \hline
\end{tabular}

${ }^{* *} p<0.01$ düzeyinde anlamlıdır.

Tablo 3'te yer alan örgütsel sinizm ile alt boyutlarının işten ayrılma niyeti ile arasındaki regresyon modeline ilişkin bulgular incelendiğinde; regresyon modelinin anlamlı olduğu $(F=93.503 ; p<0.01)$ ve örgütsel sinizmin, işten ayrılma niyeti değişkenindeki değişimin \% 35.3'ünü $\left(R^{2}=.353\right)$ açıkladığı görülmektedir. Örgütsel 
sinizmin bilişsel boyutunun, işten ayrılma niyeti değişkeni üzerinden anlamlı bir etkisinin bulunmadığı $(\mathrm{p}=$ $.280 ; \mathrm{p}<0.01)$ fakat duyuşsal $(\beta=.523 ; \mathrm{p}<0.01)$ ve davranışsal $(\beta=.151 ; \mathrm{p}<0.01)$ boyutlarının işten ayrılma niyetini pozitif yönde ve anlamlı bir biçimde etkiledikleri tespit edilmiştir. Buna göre Araştırmada geliştirilen $\mathrm{H}_{1}, \mathrm{H}_{3}$ ve $\mathrm{H}_{4}$ hipotezleri desteklenmiştir. Ancak "Bilişsel sinizmin, işten ayrılma niyeti üzerinde pozitif etkisi vardır" şeklinde geliştirilmiş olan $\mathrm{H}_{2}$ hipotezi desteklenmemiştir. Buna bağlı olarak "Bilişsel sinizmin, işten ayrılma niyeti üzerindeki etkisinde yaşın düzenleyici etkisi vardır" şeklinde ifade edilen $\mathrm{H}_{6}$ hipotezi anlamını yitirmektedir. Dolayısıyla düzenleyici değişken analizleri yapılırken $\mathrm{H}_{6}$ hipotezi kapsam dışı bırakılmıştır.

Araştırmada yaş değişkenin düzenleyici bir etki göstererek örgütsel sinizmin ve alt boyutlarının işten ayrılma niyeti üzerindeki etkisinde değişime neden olup olmadığ düzenleyici değişken etkisini test etmeye yarayan, SPSS için geliştirilmiş olan PROCESS Makro (Hayes, 2012) yama uygulaması kullanılmıştır. PROCESS Makro, düzenleyici değişken analizleri ile ilgili olarak gerçekleştirilen çeşitli çalışmalarda sıklıkla kullanılan bir yama uygulamasıdır (Albaiti \& Melhem, 2017: 30; Özşahin, Bayarçelik \& Yıldız, 2017: 754; Priesemuth \& Taylor, 2016: 967). Yapılan analizlere ilişkin elde edilen bulgular Tablo 4'te gösterilmektedir.

Tablo 4. Düzenleyici Değişken Analizlerine İlişkin Bulgular

Bağımlı Değişken: İşten Ayrılma Niyeti

\begin{tabular}{lcccc}
\hline Bağımsız Değ. X Moderatör Değ. & $\boldsymbol{\beta}$ & $\mathbf{S S}$ & $\mathbf{t}$ & $\mathbf{p}$ \\
\hline \hline Örgütsel Sinizm X Yaş & 1.153 & .656 & 1.761 & .735 \\
$>\quad$ Duyuşsal Sinizm X Yaş & 2.079 & .460 & 4.513 & .948 \\
$>$ Davranışsal Sinizm X Yaş & 3.060 & .451 & 6.774 & .899 \\
\hline \hline
\end{tabular}

Tablo 4'te PROCESS Makro kullanılarak yapılan düzenleyici değişken analizlerine ait bulgular incelendiğinde; örgütsel sinizmin ve alt boyutları olan duyuşsal ve davranışsal boyutlarının işten ayrılma niyeti üzerindeki etkisinde yaş değişkeninin anlamlı bir düzenleyiciliğinin bulunmadığı görülmektedir. Buna göre araştırma kapsamında geliştirilen $\mathrm{H}_{5}, \mathrm{H}_{7}$ ve $\mathrm{H}_{8}$ hipotezleri desteklenmemektedir.

\section{Tartışma ve Sonuç}

Araştırmanın sorunsalı kapsamında, polislik mesleğine özgü olarak yaş değişkenin örgütsel konularla baş etmede düzenleyici bir etkisinin olabileceği değerlendirilmiştir. Dolayısıyla yaş değişkenin polislik mesleğinin beraberinde getirdiği sorunlara yaklaşımda belirgin bir düzenleyici etkisinin olacağ edilmiştir. Ancak araştırmada elde edilen sonuçlar öngörülenden farklı çıkarak yaş değişkeninin polislerin örgütsel sinizme bağlı olarak işten ayrılmalarına yönelmelerinde herhangi bir düzenleyici etkisinin olmadığını ortaya koymaktadır. Elde edilen bu sonuç her ne kadar tahmin edilenden farklı olsa da çeşitli yönleri itibariyle yazına katkı sağlayabilecek önemli bir sonuçtur. Her şeyden önce ekonomik sistem içerisinde ortalamanın üzerinde maaş ve sosyal haklara sahip olan polisler arasında işten ayrılma düşüncesinin yaygın bir hal alması üzerinde düşünülmesi ve araştırılması gereken bir konudur. Bu çalışma ile polislerin işten ayrılma konusundaki eğilimleri hakkında sonraki çalışmaların faydalanabileceği sonuçlar elde edilmiştir.

Polisler de her çalışan gibi olabilecek çeşitli sebeplerden dolayı işten ayrılmaya karar verebilir veya bu niyette olabilir. Çalışanların işten ayrılma niyetlerinin sebeplerinden biri de kuşkusuz örgütsel sinizmdir. Örgütsel sinizmin polisler arasında farklı düzeylerde algılanabildiği görülmektedir. Ayrıca araştırma bulgularına göre örgütsel sinizmin boyutlarından biri olan duyuşsal sinizmin diğer boyutlara göre işten ayrılma niyeti üzerinde daha kuvvetli bir etkiye sahip olduğu anlaşılmaktadır. Bu durum polislerin inanç veya bilişsel boyut konusunda kendini rahat bir biçimde ifade edemediklerini akla getirmektedir. Örgütsel sinizm ölçeğindeki sinizmin davranışsal boyutunu ölçme amacı taşıyan ifadelerde yer alan davranışlar esasında polislerin günlük yaşamda rahat bir biçimde geliştirebilecekleri davranışlar olarak görülmemelidir. Polislerin tabi oldukları disiplin mevzuatı hem emniyet teşkilatını hem de amirlerini ve üstlerini ima yoluyla bile olsa eleştirmeyi kesin bir biçimde yasaklamakta ve bunun ihlal edilmesi durumunda meslekten çıkarmaya kadar varabilecek cezalar söz konusu olabilmektedir. Bu durum göz önünde bulundurulduğunda polislerin örgütsel sinizmin davranış boyutunda yer alan ifadelerdeki davranışları geliştirmeleri mümkün 
olamamaktadır. Ancak örgütsel sinizmin duyuşsal boyutu polislerin daha çok kendi içlerinde ve kendiliğinden gelişen duygusal tepkilerdir. Bu yönüyle polislere yöneltilen sorularda duyuşsal boyuttaki ifadelerin işten ayrılma niyetindeki değişimi açıklama oranının daha güçlü çıkmasına imkân verebiliyor olabilir.

Çağdaş örgütler çalışanlar ile ilgili farkındalıklarını her geçen gün daha çok artırmak durumundadırlar. Çeşitli yapısal ve örgütsel konuların çalışanlar üzerinde önemli etkilerinin olduğunun bilinmesi ve buna göre çeşitli tedbirler alınması gerekmektedir. Polis teşkilatı özelinde polislerin neden daha düşük sosyal güvenceye ve daha düşük ücrete sahip işlere bir yönelim olduğunun araştırılması ve tespit edilen aksaklıkların giderilmesi güvenlik hizmetlerin ulusal düzeyde kalitesinin artmasına, insanların daha mutlu bir iş ve aile yaşamına sahip olmalarına, polislerin görevlerini daha yüksek bir motivasyonla gerçekleştirmelerine imkân verebilir.

\section{Kaynaklar}

Abraham, R. (2000). Organizational Cynicism: Bases and Consequences. Genetic, Social, and General. Psychology Monographs, 126 (3), 269-292.

Albaity, M. \& Melhem, S. B. (2017). Novelty Seeking, Image, and Loyalty-The Mediating Role of Satisfaction and Moderating Role of Length of Stay: International Tourists' Perspective. Tourism Management Perspectives, 23, 30-37.

Altunışık, R., Coşkun, R., Bayraktaroğlu, S. \& Yıldırım, E. (2004). Sosyal Bilimlerde Araştırma Yöntemleri: SPSS Uygulamalı. İstanbul: Sakarya Kitabevi.

Appollis, V. P. (2010). The Relationship Between Intention to Quit, Pyschological Capital and Job Satisfaction in The Tourism Industry in The Western Cape. Doctoral Dissertation, Western Cape: University of The Western Cape.

Balay, R., Kaya, A. \& Cülha, A. (2013). Örgüt Kültürü Ve Örgütsel Sinizm İlişkisi. C.Ü. İktisadi İdari Bilimler Dergisi, 14(2), 123-132.

Beğenirbaş, M. \& Çalışkan, A. (2014). Duygusal Emeğin İş Performansı ve İşten Ayrılma Niyetine Etkisinde Kişilerarası Çarpıklığın Aracılık Rolü. Business and Economics Research Journal, 5(2), 109-127.

Beheiri, L. A., Ahmed, E. S. \& Aboul Ela, G. M. (2018). Analyzing the Effect of Organization Cynicism on Intention to Leave: A Case Study on Nola Cupcakes. IOSR Journal of Business and Management, 20(6), 20-26.

Bernerth, J. B., Armenakis, A. A., Field, H. S. \& Walker, H. (2007). Justice, cynicism, and Commitment A Study of Important Organizational Change Variables. The Journal of Applied Behavioral Science, 43(3), 303-326.

Bibby, C. L. (2008). Should I Stay or Should I Leave? Perceptions of Age Discrimination, Organizational Justice and Employee Attitudes on Intentions to Leave. Journal of Applied Management and Enterpreneurship, 13(2), 63-86.

Bolat, T., Bolat, O. İ., Seymen, O. \& Katı, Y. (2017). Otellerde nepotizm (akraba kayırmacılı̆̆ı) ve işten ayrılma niyeti ilişkisi: kariyer düzleşmesinin aracılık etkisi. Manas Sosyal Araştırmalar Dergisi, 6(3), 157-180.

Byrne, Z. S. \& Hochwarter, W. A. (2008). Perceived Organizational Support and Performance. Relationships Across Levels of Organizational Cynicism. Journal of Managerial Psychology, 23(1), 54-72.

Cammann, C. , Fichman, M., Jenkins, G. D. \& Klesh, J. R. (1983). The Michigan Organizational Assessment Survey: Conceptualization and Instrumentation (Ed.: Stanley E. Seashore, Edward E. Lawler, Philip H. Mirvis ve Cortlandt Cammann), Assessing Organizational Change: A Guide to Methods, Measures and Practices, New York: Wiley Interstice.

Canbek, M. (2017). Rol Belirsizlĭgi ve Rol Çatışmasının, İşten Ayrılma Niyeti Üzerindeki Etkisinde Duygusal Zekânın Düzenleyici Rolü. Yayımlanmamış Doktora Tezi, Gaziosmanpaşa Üniversitesi, Sosyal Bilimler Enstitüsü, İşletme Ana Bilim Dalı, Tokat. 
Çakıcı, A. \& Doğan, S. (2014). Örgütsel Sinizmin İş Performansına Etkisi: Meslek Yüksekokullarında Bir Araştırma. Doğuş Üniversitesi Dergisi, 15(1), 79-89.

Çelik, M. \& Çıra, A. (2013). Örgütsel Vatandaşlık Davranışının İş Performansı ve İşten Ayrılma Niyeti Üzerine Etkisinde Aşırı İş Yükünün Aracılık Rolü. Ege Akademik Bakış, 13(1), 11- 20.

Davis, W. D. \& Gardner, W. L. (2004). Perceptions of Politics And Organizational Cynicism: An Attributional and Leader-Member Exchange Perspective. The Leadership Quarterly, 15, 439-465.

Davis, W. D. \& Gardner, W. L. (2004). Perceptions of Politics and Organizational Cynicism: An Attributional and Leader-Member Exchange Perspective. Leadership Quarterly, 15, 439-465.

Dean, J., Brandes, P. \& Dharwadkar, R. (1998). Organizational Cynicism. The Academy of Management Review, 3(2), 341-352.

Demir, M. \& Tütüncü, Ö. (2010). Ağırlama İşletmelerinde Örgütsel Sapma ile İşten Ayrılma Eğilimi Arasındaki İlişki. Anatolia: Turizm Araştırmaları Dergisi, 21(1), 64-74.

Emberland, J. S. \& Rundmo, T. (2010). Implications of Job Insecurity Perceptions and Job Insecurity Responses for Psychological Well-Being, Turnover Intentions and Reported Risk Behavior. Safety Science, 48(4), 452-459.

Erarslan, S., Kaya, Ç. \& Altındağ, E. (2018). Effect of Organizational Cynicism and Job Satisfaction on Organizational Commitment: An Empirical Study on Banking Sector. Suleyman Demirel University Journal of Faculty of Economics \& Administrative Sciences, 23, 905-922.

Erbil, S. (2013). Otel İşletmelerinde Çalışanların Örgütsel Sinizm Algılarının İşten Ayrılma Niyetine Etkisi. Yayınlanmamış Yüksek Lisans Tezi, Adnan Menderes Üniversitesi Sosyal Bilimler Enstitüsü, Aydın.

Erdost, H. E., Karacaoğlu, K. \& Reyhanoğlu, M. (2007). Örgütsel Sinizm Kavramı ve İlgili Ölçeklerin Türkiye'deki Bir Firmada Test Edilmesi. 15. Ulusal Yönetim ve Organizasyon Kongresi Bildiri Kitabı, 514-524.

Erkuş, A. \& Fındıklı, M. A. (2013). Psikolojik Sermayenin İş Tatmini, İş Performansı ve İşten Ayrılma Niyeti Üzerindeki Etkisine Yönelik Bir Araştırma. İstanbul Üniversitesi İşletme Fakültesi Dergisi, 42(2), 302318.

Genç, N. (2013). Yönetim ve Organizasyon - Çağdaş Sistemler ve Yaklaşımlar. 4. Baskı, İstanbul: Seçkin Yayınevi.

Güzel, B. \& Ayazlar, G. (2014). Örgütsel Adaletin Örgütsel Sinizm ve İşten Ayrılma Niyetine Etkisi: Otel İşletmeleri Araştırması. KMÜ Sosyal ve Ekonomik Araştırmalar Dergisi, 16(26), 133-142.

Gürbüz, S. \& Şahin, F. (2016). Sosyal Bilimlerde Araştırma Yöntemleri. Ankara: Seçkin Yayıncılık.

James, M. (2005). Antecedents and Consequences of Cynicism in Organizainons: An Examination of the Potential Positive and Negative Effects on School Systems. Dissertation of Doctor of Philosophy, The Florida State University, Florida.

Kalağan, G. (2009) Araştırma Görevlilerinin Örgütsel Destek Algıları İle Örgütsel Sinizm Tutumları Arasındaki İlişki. Yayımlanmamış Yüksek Lisans Tezi, Akdeniz Üniversitesi, Antalya.

Kanbur, A. \& Kanbur, E. (2015). Lider-Üye Etkileşiminin Örgütsel Sinizme Etkisi: Algılanan İçsellik Statüsünün Aracılık Rolü. Zeitschrift für die Welt der Türken/Journal of World of Turks, 7(2), 193-216.

Kanbur, E. (2018). Havacılık Sektöründe Psikolojik Güçlendirme, İş Performansı ve İşten Ayrılma Niyeti Arasındaki İlişkilerin İncelenmesi. Uluslararası Yönetim İktisat ve İşletme Dergisi, 14(1), 147-162.

Kanbur E. \& Canbek M. (2018), Algılanan Örgütsel Adaletin Örgütsel Sinizm Üzerine Etkisi: Algılanan Örgütsel Desteğin Aracılık Rolü. BMIJ, 6(3), 36-57.

Karacaoğlu, K. \& İnce, F. (2012). Brandes, Dhadwadkar ve Dean'in (1999) Örgütsel Sinizm Ölçeği Türkçe Formunun Geçerlilik Ve Güvenilirlik Çalışması: Kayseri Organize Sanayi Bölgesi Örneği. Business and Economics Research Journal, 3(3), 77-92.

Kerse, G. \& Karabey, C. N. (2017). Algılanan örgütsel desteğin örgütsel özdeşleşmeye etkisi: Örgütsel sinizmin aracı rolü. MANAS Sosyal Araştırmalar Dergisi, 6(4), 375-398.

Korkmaz, C. İ. (2011). Kişilik Sinizmi ve Algılanan Üst Yönetim Desteğinin Örgütsel Sinizm Üzerindeki Etkisini İncelemeye Yönelik Bir Araştırma. Yayımlanmamış Yüksek Lisans Tezi. Marmara Üniversitesi, Sosyal Bilimler Enstitüsü, İşletme Ana Bilim Dalı, Yönetim ve Organizasyon Bilim Dalı, İstanbul. 
M. Canbek - E. Kanbur 11/3 (2019) 1493-1502

Mert, G. \& Yılmaz, G. (2019). Beş Yıldızlı Otellerde Örgütsel Sinizmin İşletme Performansına Etkisinde Motivasyon Rolünün İncelenmesi. Electronic Turkish Studies, 14(2), 629-650.

Mimaroğlu, H. (2008). Psikolojik Sözleşmenin Personelin Tutum ve Davranışlarına Etkileri: Tıbbi Satış Temsilcileri Üzerinde Bir Araştırma. Satış Temsilcileri Üzerinde Bir Araştırma. (Yayımlanmamış Doktora Tezi). Çukurova Üniversitesi Sosyal Bilimler Enstitüsü, Adana.

Naus, F., Iterson, V. A. \& Roe, R. A. (2007). Value Incongruence, Job Autonomy, and OrganizationBased Self-Esteem: A Self-Based Perspective on Organizational Cynicism. European Journal of Work and Organizational Psychology, 16(2), 195-219.

Onay, M. \& Kılcı, S. (2011). İş Stresi ve Tükenmişlik Duygusunun İşten Ayrılma Niyeti Üzerine Etkileri: Garsonlar ve Aşçlar. Organizasyon ve Yönetim Bilimleri Dergisi, 3(2), 363-372.

Özşahin, M., Bayarçelik, E. B. \& Yıldız, B. (2017). Strateji Tipleri İle Yenilik Performansı İlişkisinde Stratejik Karar Verme Hızının Şartı Değişken (Moderatör) Etkisi. Uluslararası İktisadi ve İdari İncelemeler Dergisi, 16. UİK Özel Sayısı, 749-766.

Polat, M. \& Meydan, C. H. (2010). Örgütsel Özdeşleşmenin Sinizm ve İşten Ayrılma Niyeti İle İlişkisi Üzerine Bir Araştırma. Kara Harp Okulu Savunma Bilimleri Sosyal Bilimler Enstitüsü Dergisi, 9(1), 145172.

Priesemuth, M. \& Taylor, R. M. (2016). The More I Want, The Less I Have Left To Give: The Moderating Role of Psychological Entitlement on The Relationship between Psychological Contract Violation, Depressive Mood States, and Citizenship Behavior. Journal of Organizational Behavior, 37(7), 967-982.

Seymen, A. O. \& Kırboğa, R. (2018). Örgütlerde Psikolojik Sözleşme İhlâli Algısı ve Örgütsel Sinizm Arasındaki İlişki: Lider-Üye Etkileşiminin Aracılık Etkisi. İşletme Bilimi Dergisi, 6(2), 189-216.

Suresh, L. \& Krishnaraj, R. (2015). A Study on The Importance of Employee Retention in Pharmaceutical Sector in India. International Journal of Pharmaceutical Sciences Review And Research, 32(1), 108 - 111.

Tanrıverdi, H., Koçaslan, G. \& Taştan, N. O. (2018). Psikolojik şiddet algısı, tükenmişlik sendromu ve işten ayrılma niyeti arasındaki ilişki: Banka çalışanları üzerinde bir araştırma. Yönetim ve Ekonomi: Celal Bayar Üniversitesi İktisadi ve İdari Bilimler Fakültesi Dergisi, 25(1), 113-131.

Tett, R. P. \& Meyer, J. P. (1993). Job Satisfaction, Organizational Commitment, Turnover Intention, and Turnover: Path Analyses Based on Metaanalytic Findings. Personnel Psychology, 46, 259-293.

Torun, Y. (2016). Personel Güçlendirme ve İşten Ayrılma Niyeti İlişkisinde Örgütsel Sinizmin Aracılık Rolü: Örgütsel Sinizm Ölçeği Geliştirmeye Yönelik Bir Araştırma. Yayımlanmamış Doktora Tezi, Marmara Üniversitesi SBE, İstanbul.

Üçok, D. \& Torun, A. (2014). Tükenmişliği Etkileyen Olumsuz Tutum Ve Beklentiler: Sinik Tutum Ve Psikolojik Sözleşme İhlali Algısı Üzerine Bir Araştırma. Atatürk Üniversitesi İktisadi Ve İdari Bilimler Dergisi, 28 (1), 231-250.

Wilkerson, J. M, Evans W. R \& Davis, W. D. (2008). A Test of Coworkers' Influence on Organiza-Tional Cynicism, Badmouthing, and Organizational Citizenship Behavior. Journal ofApplied Social Psychology, 38, 2273-2292.

Yalçın, U. (2017). Araştırma Görevlilerinin Örgütsel Sinizm Algılarının İşten Ayrılma Niyetine Etkisi. Yayımlanmamış Yüksek Lisans Tezi, Atatürk Üniversitesi, Sosyal Bilimler Enstitüsü, Spor Yönetim Bilimleri Anabilim Dalı, Erzurum.

Yasım, Y. K. \& Uğur, A. (2016). Bankacı Kadınların Örgütsel Sinizmin Algılarının İşten Ayrılma Niyetine Etkisi: Ordu İli Örneği. ODÜ Sosyal Bilimler Araştırmaları Dergisi (ODÜSOBİAD), 6(15), 554-572.

Yıldız, K. (2013). Örgütsel Bağlılık ile Örgütsel Sinizm ve Örgütsel Muhalefet Arasındaki İlişki. Turkish Studies, 8(6), 853-879.

Yürür, Ş. \& Ünlü, Ö. (2011). Duygusal Emek, Duygusal Tükenme ve İşten Ayrılma Niyeti İlişkisi. İş, Güç; Endüstri İlişkileri ve İnsan Kaynakları Dergisi, 13(2), 81-104. 